\title{
The Integrated PBL-DMM: A Learning Model to Enhance Student Creativity
}

\author{
Nurkhairo Hidayati ${ }^{1}$, Siti Zubaidah ${ }^{2}$, Endang Suarsini ${ }^{3}$, Henry Praherdhiono ${ }^{4}$
}

$1 \quad$ Universitas Negeri Malang, Biology Education Department, ID-65145, Malang, East Java Province, Indonesia; Universitas Islam Riau, Biology Education Department, ID-28284, Pekanbaru, Indonesia, khairobio@edu.uir.ac.id

2 Universitas Negeri Malang, Biology Education Department, ID-65145, Malang, East Java Province, Indonesia, siti.zubaidah.fmipa@um.ac.id

3 Universitas Negeri Malang, Biology Education Department, ID-65145, Malang, East Java Province, Indonesia, endang.suarsini.fmipa@um.ac.id

4 Universitas Negeri Malang, Educational Technology Department, ID-65145, Malang, East Java Province, Indonesia, henrypraherdhiono.fip@um.ac.id

\begin{abstract}
The present study aimed to test the effectiveness of two learning models, namely Problem-Based Learning (PBL) and Integrated Problem-Based Learning and Digital Mind Maps (PBL-DMM) in improving student creativity. This experiment employed a pretest-posttest control group design and involved 103 participants. An essay test was used to evaluate the participants' creativity. The results showed that both PBL and PBL-DMM had an effect on creativity, yet among these two learning models, PBL-DMM was considered more effective to boost student creativity.
\end{abstract}

Keywords: Learning Model, Student Creativity, Problem-Based Learning, Digital Mind Maps.

\section{Introduction}

Changes and a more competitive landscape in the $21^{\text {st }}$ century require colleges and universities to be extra conscientious in preparing their graduates to embark on the work field and possess various skills needed for a particular job (Frydenberg \& Andone, 2011). The 21st-century skills help learners to adapt to new changes. In other words, only those who have the knowledge and skills to deal with and adjust to new situations can succeed in this era of technology (Ongardwanich, Kanjanawasee, \& Tuipae, 2015; Pheeraphan, 2013). Therefore, besides being academically challenged, university students also need to be socially skillful and competent in the workplace (Turiman, Omar, Daud, \& Osman, 
2012). Among the many important skills that need to be mastered by the students to survive in the current century, creativity should be considered paramount (Chu et al., 2017; Tan, Lee, Ponnusamy, \& Koh, 2016).

Creativity includes an effort of finding the unknown, developing new solutions to every problem encountered, and putting things together in a new and different way (Hoseinifaret al., 2011; Reid \& Petocz, 2004). Creativity produces new, varied, and unique ideas (Batey, 2012). Creativity is part of the $21^{\text {st }}$-century skills (Chan \& Yuen, 2014) so that it needs to be empowered through learning (Csikszentmihalyi, 2012). Creativity plays a key role in the advancement of human civilization and affects human lifestyles (Chang, Wang, \& Lee, 2016). It has social and economic implications and a positive effect on individuals' personality aspects (Chen, 2016). Yates \& Twigg (2017) adds that by fostering creativity over the years, education can create an imaginative thinkers community. Creativity can act as an important aspect of competitiveness with innovation as its focus (Kuo et al., 2017).

The development of creativity is increasingly seen as a necessity in the field of education because creativity can encourage students to perform better (Hansenne\&Legrand, 2012; Yusnaeni, Corebima, Susilo, \& Zubaidah, 2017) and influence their future success (Castillo-vergara et al., 2018). However, numerous studies in Indonesia have reported the inability of university students to think creatively (e.g., Darmawan, 2014; Musadad, 2011). The importance of creativity has not been accommodated by a supportive learning process because some educators may not have the right pedagogical strategies to do so (Birsa, 2018; Chan \& Yuen, 2014). In fact, most teachers consider students smarter when they can acquire, remember, and apply information that opposes creative perspectives (Brand, Hendy, \& Harrison, 2015). Inflexible classroom rules and rigid learning environments can also prevent the students from thinking creatively (Castillo-vergara et al., 2018).

Referring to the explanations above, it can be ensured that to be ready to face $21^{\text {st }}$-century challenges, university students need creativity. Given the facts, that the majority of the students lack in this creativity, it is thus essential to discuss the importance of active learning strategies (Fuad, Zubaidah, Mahanal, Suarsini, 2017; Kim, Sharma, Land, \& Furlong, 2013) in the classroom. Active learning strategies which involve the use of open-ended tasks can be useful in helping students to solve problems (Huang, 2017; Wu, Chang, \& Chen, 2017). These strategies can also assist students in extracting information so that they can decide on further actions (Vong \& Kaewurai, 2017). One of the examples of learning models that employ active learning strategies is Problem-Based Learning (PBL).

PBL is a learning model that prioritises the process of working in groups towards problems resolution (O'Grady et al., 2012). PBL incorporates two pillars of learning theory, namely social constructivism and cognitive constructivism (Wyness \& Dalton, 2018). PBL facilitates students in contextualizing knowledge and practice (Applin, Williams, Day, \& Buro, 2011). Tutorials, facilitation, problem-solving, independent learning, collaboration, and post-problem reflection are the key elements of PBL (Bridges, McGrath, $\&$ Whitehill, 2012). PBL can also be implemented in three stages: (1) pre-discussion, (2) 
self-study period, and (3) presentation of results (Hmelo-Silver, 2004; Loyens, Kirschner, \& Paas, 2012).

PBL has been proven effective to improve student creativity. Students in PBL classes are more able to demonstrate professional skills such as communication, collaboration, innovation, and creativity than those who learn using traditional approaches (Alrahlah, 2016; Loyens et al., 2006; Bridges et al., 2012). PBL presents an appropriate learning environment to develop individual creativity (Siew, Chin, \& Sombuling, 2017; Ulger, 2018; Zhou, 2015), so students can activate their prior knowledge and develop various skills (Gijbels, Dochy, Van den Bossche, \& Segers, 2005).

However, PBL still has weaknesses in developing student creativity related to the nature of science (Moutinho et al., 2015). Since PBL mainly focuses on the elaboration of a student' prior knowledge and reflection on problem-solving processes, students rarely try to brainstorm ideas (Dell, Garrick, Romanowski, \& Slifka, 2012). As a matter of fact, the activation of a student' prior knowledge allows the simulation of links between new and old information. However, brainstorming of ideas such as mind mapping can help students visualize previous knowledge in a broader conceptual form (Johnstone \& Otis, 2006). Mind maps can develop student creativity (Siwczuk, 2005), assist students in summarizing PBL discussions, and enable student reflection on the learning process (Ravindranath, Abrew, De, \& Nadarajah, 2016). As mind maps can act as a mediator in connecting one concept and another, this study attempted to integrate PBL and mind mapping (Hariyadi, Corebima, \& Zubaidah, 2018).

Mind maps are diagrams arranged radially and sequentially. These diagrams are used to represent related concepts and ideas (Cuthell \& Preston, 2008) using words, images, colors, and branches. Mind maps which are made digitally using technology (Laampere, Matsak, \& Kippar, 2006; Siwczuk, 2005) are known as Digital Mind Maps (DMM). DMM comes in various forms of technology. These mind maps are created using technology-based applications to brainstorm and present ideas (Faste \& Lin, 2012). They are arranged in a non-linear format with colors, numbers, fonts, images, or video (Papushina, Maksimenkova, \& Kolomiets, 2017; Simonova, 2015). Considering the role of information technology in student self-development (Turganbayeva \& Moshkalov, 2013), DMM can be used to facilitate learning (Pumahapinyo \& Suwannatthachote, 2014; Simándi, 2018).

The integration of PBL and DMM (Integrated PBL-DMM) can be expected to promote student engagement in creative problem-solving (Noonan, 2013). The activity of connecting images to concepts when drawing DMM is a creative task that requires thinking rather than memorizing (Papushina et al., 2017). The use of digital teaching can motivate students and make the learning process more interesting (Lebeničnik, Pitt, \& Starčič, 2015; Qi, 2018). DMM can be saved as files, and those files can be shared between students and educators so that educators and students can collaborate more easily (Erdogan, 2009).

Based on the description in the background, the purpose of this study was to investigate the effect of two learning models, namely PBL and PBL-DMM on creativity. It was hypothesized that both PBL and PBL-DMM affected university students' creativity. 


\section{Methods}

\section{Research Design}

This research employed a pretest-posttest control group design (Fraenkel \& Wallen, 2009) this research design was appropriate to test the research hypotheses. The pretest and post-test were conducted to the three treatment groups (PBL, PBLDMM, and control). The data gathered from the control group were thus compared to the data obtained from the experimental groups. Learning models (PBL, PBLDMM, and traditional) were assigned as the independent variables of this study, whereas creativity acted as the dependent variable. The design of the study can be seen in Table 1.

Table 1

Research Design

\begin{tabular}{ccc}
\hline Pretest & Treatment Group & Posttest \\
\hline O1 & Traditional & O2 \\
\hline O3 & PBL & O4 \\
\hline O5 & PBL-DMM & O6 \\
\hline
\end{tabular}

Notes:

Traditional:Students who conducted learning using traditional methods

PBL : Students who conducted learning using PBL

PBL-DMM : : Students who conducted learning using PBL-DMM

O1, O3, O5 : pretest scores

O2, O4, : posttest scores

\section{Research Samples}

This experiment was carried out in the even semester of the 2017/2018 academic year. The research participants consisted of 103 students aged 19-20 years and had been registered for "Human Physiology and Anatomy" class. These students came from a university in Riau, which is located in Indonesia. Before selecting the samples, a test was distributed to the participants. This test contained 30 multiple-choice items which covered topics around animal development, cell biology, microbiology, and biochemistry. The test materials had been learned by the research participants in the previous semesters, so they could be used as the basis to examine the students' academic achievement. The test result would determine three classes with equivalent academic ability. Each of the classes was randomly picked to act as the PBL group (37 students), PBL-DMM group (35 students), and traditional group (31 students). 


\section{Data Collection Tools and Procedure}

The data of this study were collected using a syllabus, lesson plans, student worksheets, and an instrument to measure student creativity. The instruments of the study consisted of an essay test and a scoring rubric. The test contained 11 questions on human anatomy and physiology (Appendix 1), while the rubric was used to assess the students' answers to the questions. The scoring rubric was developed on the indicators of creativity adapted from Greenstein (2012), namely originality, fluency, flexibility, elaboration, and risk-taking. The creativity rubric is presented in Table 2.

\section{Table 2}

Creativity Rubric

\begin{tabular}{|c|c|c|c|c|c|}
\hline \multirow{2}{*}{ No } & \multirow{2}{*}{ Indicator } & \multicolumn{4}{|c|}{ Score } \\
\hline & & 4 & 3 & 2 & 1 \\
\hline 1 & Originality & $\begin{array}{l}\text { Ideas are new and } \\
\text { unique. No one has } \\
\text { thought of them } \\
\text { before }\end{array}$ & $\begin{array}{l}\text { Ideas are unique and } \\
\text { can be used to pro- } \\
\text { duce something new }\end{array}$ & $\begin{array}{l}\text { Ideas mostly re- } \\
\text { semble others' }\end{array}$ & $\begin{array}{l}\text { Unable to } \\
\text { express a new } \\
\text { or unique idea }\end{array}$ \\
\hline 2 & Elaboration & $\begin{array}{l}\text { Very proficient in } \\
\text { using the ability to } \\
\text { add certain details } \\
\text { to ideas/work so } \\
\text { that they can look } \\
\text { much better }\end{array}$ & $\begin{array}{l}\text { Able to add some de- } \\
\text { tails to ideas/work } \\
\text { so that they can look } \\
\text { much better }\end{array}$ & $\begin{array}{l}\text { Not very proficient } \\
\text { in placing some de- } \\
\text { tails to ideas/work } \\
\text { so that the results } \\
\text { are not very satis- } \\
\text { fying }\end{array}$ & $\begin{array}{l}\text { Unable to think } \\
\text { of certain ways } \\
\text { to better an } \\
\text { idea/work }\end{array}$ \\
\hline 3 & Flue & $\begin{array}{l}\text { Very fluent in pro- } \\
\text { ducing ideas }(>= \\
\text { 5) relevant to the } \\
\text { problem }\end{array}$ & $\begin{array}{l}\text { Able to produce some } \\
\text { ideas }(2-4) \text { relevant } \\
\text { to the problem }\end{array}$ & $\begin{array}{l}\text { Able to produce } \\
\text { some ideas }(2-4) \\
\text { which are some- } \\
\text { times irrelevant to } \\
\text { the problem }\end{array}$ & $\begin{array}{l}\text { Only able to } \\
\text { produce one } \\
\text { single idea }\end{array}$ \\
\hline 4 & Flex & $\begin{array}{l}\text { Able to adjust the } \\
\text { existing prob- } \\
\text { lem-solving ap- } \\
\text { proach to a new } \\
\text { situation }\end{array}$ & $\begin{array}{l}\text { Able to adjust the ex- } \\
\text { isting problem-solv- } \\
\text { ing approach to a new } \\
\text { situation but experi- } \\
\text { ence trouble in pro- } \\
\text { viding reasons un- } \\
\text { derlying the change }\end{array}$ & $\begin{array}{l}\text { Able to adjust the } \\
\text { existing prob- } \\
\text { lem-solving ap- } \\
\text { proach to a new } \\
\text { situation but can- } \\
\text { not explain why }\end{array}$ & $\begin{array}{l}\text { Unable to } \\
\text { adjust the ex- } \\
\text { isting prob- } \\
\text { lem-solving } \\
\text { approach to a } \\
\text { new situation }\end{array}$ \\
\hline 5 & $\begin{array}{l}\text { Risk- } \\
\text { Taking }\end{array}$ & $\begin{array}{l}\text { Be courageous } \\
\text { enough to try or } \\
\text { do something new } \\
\text { to take lessons } \\
\text { from it }\end{array}$ & $\begin{array}{l}\text { Willing to try or do } \\
\text { something new with- } \\
\text { out acting beyond } \\
\text { existing guidelines } \\
\text { or instructions }\end{array}$ & $\begin{array}{l}\text { Refrain from do- } \\
\text { ing something } \\
\text { that might cause } \\
\text { trouble }\end{array}$ & $\begin{array}{l}\text { Have concerns } \\
\text { about and } \\
\text { most likely to } \\
\text { avoid things } \\
\text { that are risky }\end{array}$ \\
\hline
\end{tabular}


Before data collection, all instruments had to undergo expert validation. Two lecturers conducted the validation of the lesson plans, student worksheets, and creativity rubric with expertise in learning and instructional materials. Each of the experts gave their evaluation based on the indicators provided on the validation sheet which comprised the identity of the lesson plans (such as subject to teach, materials coverage, and others), the indicators of the student learning achievement, the details of the classroom activities, the topics that are going to be discussed, and the use of language in the documents. The results showed high scores for the validity of the lesson plans, student worksheets, and creativity rubric $(95.42,94.58$, and 96.15 , respectively).

To measure the validity and reliability of the creativity test, the test was tried out to 101 students who were studying human anatomy and physiology. Statistical analysis was run, and the result indicated that the test was valid since $r$-calculated $>$ r-table. R-calculated for each item of the test was recorded in Table 3 . The test reliability was determined using Cronbach's Alpha test, and the result confirmed the reliability of the instrument with a value of 0.750 .

Table 3

The Results of the Creativity Test Validation

\begin{tabular}{cccc}
\hline Item & Pearson Correlation & Sig. (2-tailed) & Remarks \\
\hline 1 & $.463^{* *}$ & 0.000 & Valid \\
\hline 2 & $.406^{* *}$ & 0.000 & Valid \\
\hline 3 & $.608^{* *}$ & 0.000 & Valid \\
\hline 4 & $.538^{* *}$ & 0.000 & Valid \\
\hline 5 & $.579^{* *}$ & 0.000 & Valid \\
\hline 6 & $.474^{* *}$ & 0.000 & Valid \\
\hline 7 & $.590^{* *}$ & 0.000 & Valid \\
\hline 8 & $.516^{* *}$ & 0.000 & Valid \\
\hline 9 & $.611^{* *}$ & 0.000 & Valid \\
\hline 10 & $.629^{* *}$ & 0.000 & Valid \\
\hline 11 & $.469^{* *}$ & 0.000 & Valid \\
\hline
\end{tabular}

*. Correlation is significant at the 0.05 level (2-tailed).

**. Correlation is significant at the 0.01 level (2-tailed).

The implementation of the models was carried out following the syllabus and steps of learning which had been planned for a semester. To guide students, worksheets were printed out and distributed to them at the beginning of the research. The worksheets contained instructions and tasks that must be done by the students at every meeting. The students were assigned in groups to complete each task. Each class learned using different approaches based on a set of predetermined criteria of the learning models (i.e., traditional learning, PBL, and PBL-DMM). 
The stages of learning in thetraditional class began with teacher's delivering learning objectives. Then, students were guided to answer questions provided on their worksheet. The teacher explained materials, and the students listened carefully to the teacher to acquire information related to the materials. The process ended with a conclusion by the teacher. The role of the teacher or the lecturer was dominant in this type of classroom. Teaching methods used in this classroom were mostly lecture and discussion.

The main feature of the PBL classroom was students' involvement. The stages of learning in the PBL class consisted of activities which (1) oriented students to problems by presenting some actual problems related to the lecture materials, (2) organized students to learn by preparing references or learning resources that can support the problem-solving processes, (3) guided students in individual or group investigations, (4) encouraged students to present the results of the problem-solving discussions in front of the classroom, and (5) directed students to reflect or evaluate the processes they use to find the solutions.

Unlike the traditional and PBL classes, the PBL-DMM class contained activities which: (1) reviewed students' initial knowledge and helped students connect with concepts learned through DMM creation, (2) directed students to problems so that students could formulate problems, (3) helped students to define learning assignments related to learning outcomes and prepare references for the problem-solving processes, (4) guided students to gather appropriate information in order to obtain explanations and solutions to the problems, (5) encouraged students to present the results of the problem-solving discussions and add details to the DMM, (6) helped students to analyze and evaluate the problem-solving processes and concluded the lesson. Students in this classroom carried out the learning process in groups.

\section{Data Analysis}

Data of the research were analysed using ANCOVA (a significance level of 0.05). If the result were significant, an LSD (Least Significance Different) test would be conducted. Before conducting the ANCOVA analysis, the data were examined using a normality test (Kolmogorov-Smirnov test) and a homogeneity test (Levene's test) ( $p>0.05)$. The results of the tests showed that the data were distributed normally ( $p$-value 0.200$)$ and homogeneous ( $p$-value $>\alpha(\alpha=0.05)$ with $p$-values 0.663 .

\section{Results}

Students' scores based on the indicators of creativity were summarized in Figure 1. 


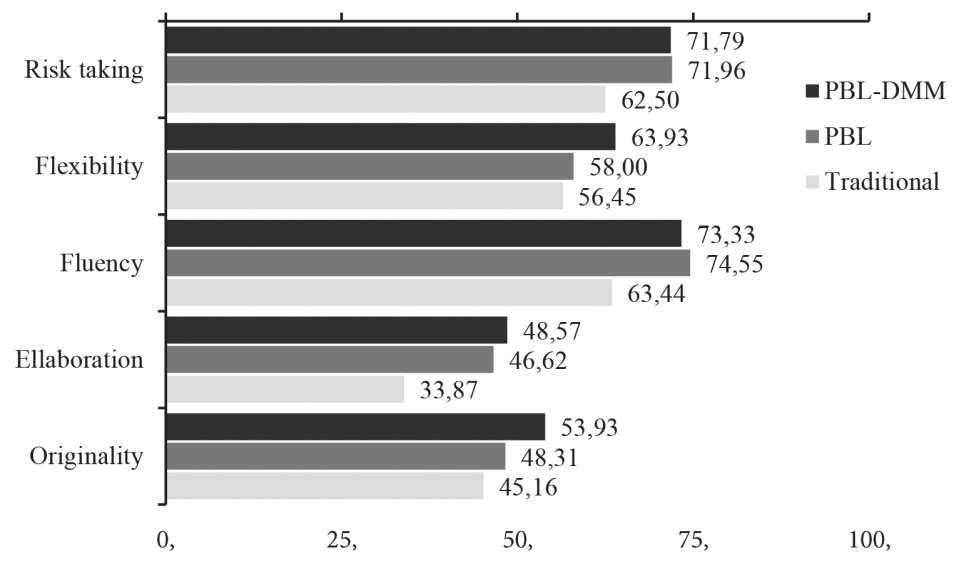

Figure 1. Students' creativity scores

Among the indicators of creativity, fluency reported the best outcomes. The highest score on fluency was found in the PBL class (74.55), followed by the PBL-DMM (73.33), and the traditional class (63.44). On the other hand, the poorest performance of the students was observed in elaboration. The average scores of elaboration of the traditional, PBL, and PBL-DMM classes were 33.87, 46.63, and 48.57, respectively.

The effects of the learning models (traditional, PBL, and PBL-DMM) on the students' creativity were determined based on the ANCOVA analysis of the students' pretest and post-test scores. The results can be seen in Table 4, followed by the LSD test presented in Table 5.

Table 4

The Results of the ANCOVA analysis on Students' Creativity

\begin{tabular}{lccccc}
\hline \multicolumn{1}{c}{ Source } & $\begin{array}{c}\text { Type III Sum } \\
\text { of Squares }\end{array}$ & df & Mean Square & F & Sig. \\
\hline Learning Models & $6705.611^{\mathrm{a}}$ & 3 & 2235.204 & 75.564 & .000 \\
\hline Intercept & 7499.508 & 1 & 7499.508 & 253.532 & .000 \\
\hline Concept & 5111.336 & 1 & 5111.336 & 172.796 & .000 \\
\hline Classes & 1230.678 & 2 & 615.339 & 20.802 & .000 \\
\hline Error & 2129.770 & 72 & 29.580 & & \\
\hline Total & 275551.633 & 76 & & & \\
\hline Total Average & 8835.381 & 75 & & & \\
\hline
\end{tabular}

a. R Squared $=.759$ (Adjusted R Squared $=.749$ ) 
Table 4 shows the difference in the results of the treatments with $p$-value $=0.000$ and $\mathrm{F}=20.802$. Since $p$-value $<\alpha(\alpha=0.05)$, the research hypothesis which said that learning models affected student creativity shall be accepted.

Table 5

The Results of the LSD Test on Student Creativity

\begin{tabular}{lccccccc}
\hline \multicolumn{1}{c}{ Class } & Pretest & Post-test & Difference & $\begin{array}{c}\text { Score } \\
\text { Increase }\end{array}$ & $\begin{array}{c}\text { Average } \\
\text { Score }\end{array}$ & LSD Notation \\
\hline Traditional & 36.881 & 52.170 & 15.289 & $41.46 \%$ & 53.292 & $\mathrm{a}$ & \\
\hline PBL & 40.236 & 61.196 & 20.960 & $52.09 \%$ & 60.058 & $\mathrm{~b}$ & \\
\hline PBL-DMM & 38.215 & 63.046 & 24.831 & $64.98 \%$ & 63.269 & & $\mathrm{c}$ \\
\hline
\end{tabular}

The results of the LSD test summarized in Table 5 show that traditional learning, PBL, and PBL-DMM had different effects on the students' creativity. The PBL-DMM class reported a significantly higher average score than the other treatment groups. In fact, the highest creativity score was observed in the PBL-DMM class, while the lowest creativity score was found in the traditional class.

\section{Discussion}

Fluency in this research reported significantly higher scores than other indicators of creativity. It can be explained by the fact that the students were able to produce several ideas relevant to the problems. When the students were asked about diarrhea and respiratory disorders, for example, they could fluently talk about clean water, sanitation, the availability of toilets, and hygienic food. This finding is in line with that of Tan, Lee, Ponnusamy, \& Koh (2016) who found fluency as a creativity dimension which can be easily mastered by students compared to other dimensions.

Fluency, indeed, showed the highest average score among all creativity indicators; however, the students were unable to accelerate in ideas elaboration. Elaboration is the ability to add details to information to make it more understandable and aesthetically pleasing (Vasilyeva \& Erdyneeva, 2016; Greenstein, 2012). The students' lack of skills in elaborating ideas can be caused by their poor concept mastery. The results of the research conducted by Wu, Cheng, Ip, \& Mcbride-chang (2005) indicate that knowledge can improve individuals' performance in creative tasks because there is a connection between task structure and knowledge base. Also, Diakidoy, Constantinou, \& Constantinou (2001) also suggest that knowledge of relevant concepts can provide the basis for appropriate creative solutions. 
Compared to elaboration, other creativity indicators such as risk-taking and flexibility have yielded better results. Risk-taking is related to the willingness to take risks because a creative individual is less worried about trying something new, even though there is uncertainty about the results. Research shows that there is a significant relationship between creativity and risk-taking (Tyagi, Hanoch, Hall, Runco, \& Denham, 2017; Simmons $\&$ Ren, 2009). While elaboration deals with the capacity to consider various approaches to solving a problem, flexibility plays an important role in assisting an individual in generating new and innovative ideas (Kenett, Levy, Kenett, Stanley, Faust, \& Havlin, 2018).

The difference in creativity scores obtained by the students in the traditional, PBL, and PBL-DMM classes can be associated with the learning processes carried out in the classrooms. The PBL-DMM class was supported by mind mapping activity that can trigger the students' creativity. The making of DMM at the early stage of learning is useful for the students to relate their background knowledge to materials being studied. Despite using the same application, the students could create different DMM. Figure 2 and 3, for example, display two different DMM which indicate that the students used distinguished patterns, colors, and branches to explain the blood circulatory system.

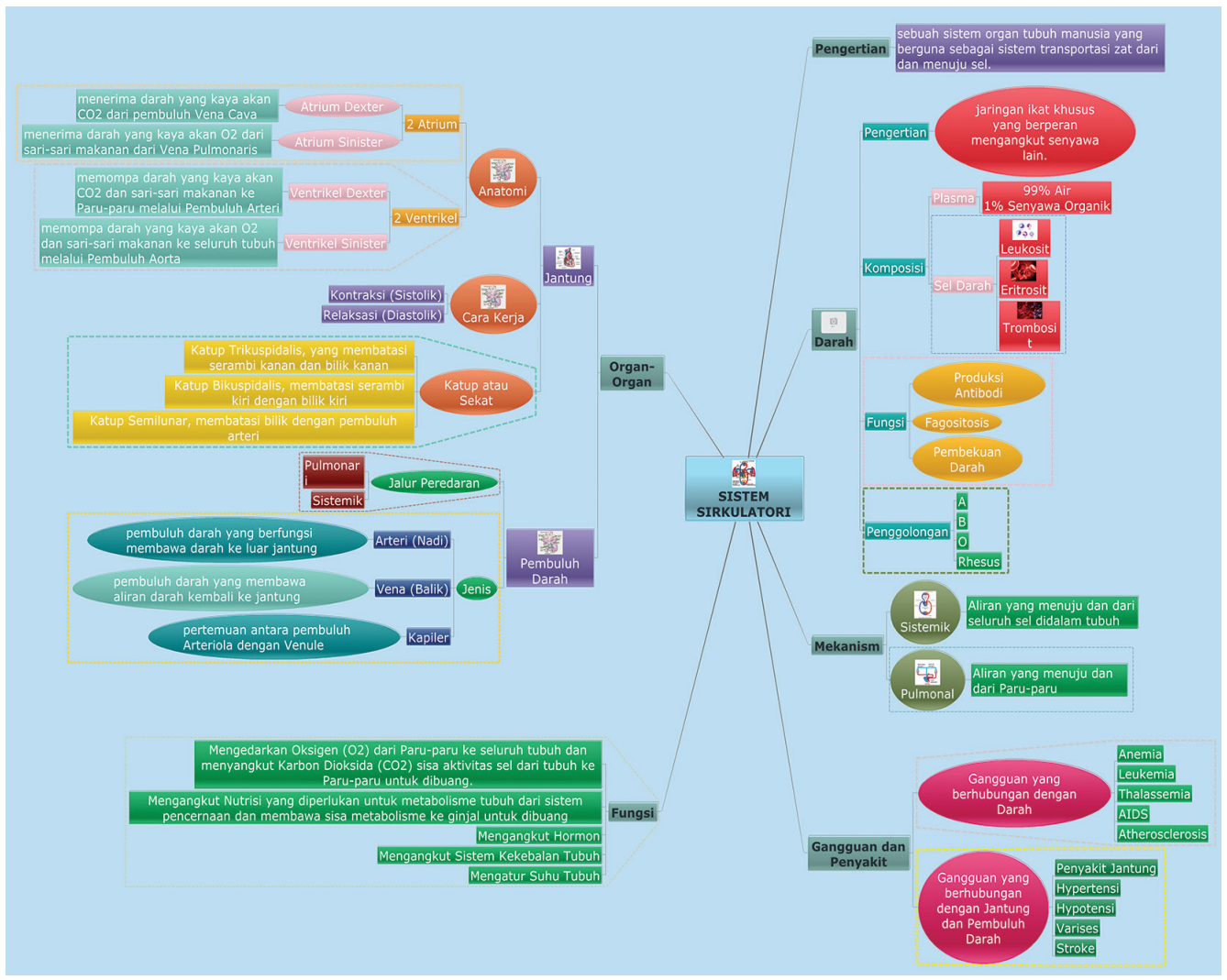

Figure 2. An Example of DMM on the Circulatory Using the Image Pattern 
In Figure 2, the student put an image of the blood circulatory system in the center of his DMM. From this point outward, the student drew straight lines to explain the following five major components: circulatory organs, blood, definition, function, and circulatory diseases.

Despite using a similar topic, the student in Figure 3 picked a different layout. Compared to Figure 2, the DMM in Figure 3 has more branches (line pattern) that discuss the definition and function of the circulatory system, blood vessels, heart, the blood circulatory mechanism, and circulatory diseases. Figure 2 and 3 thus indicate that every student may employ a distinctive way to construct a DMM based on their ideas.

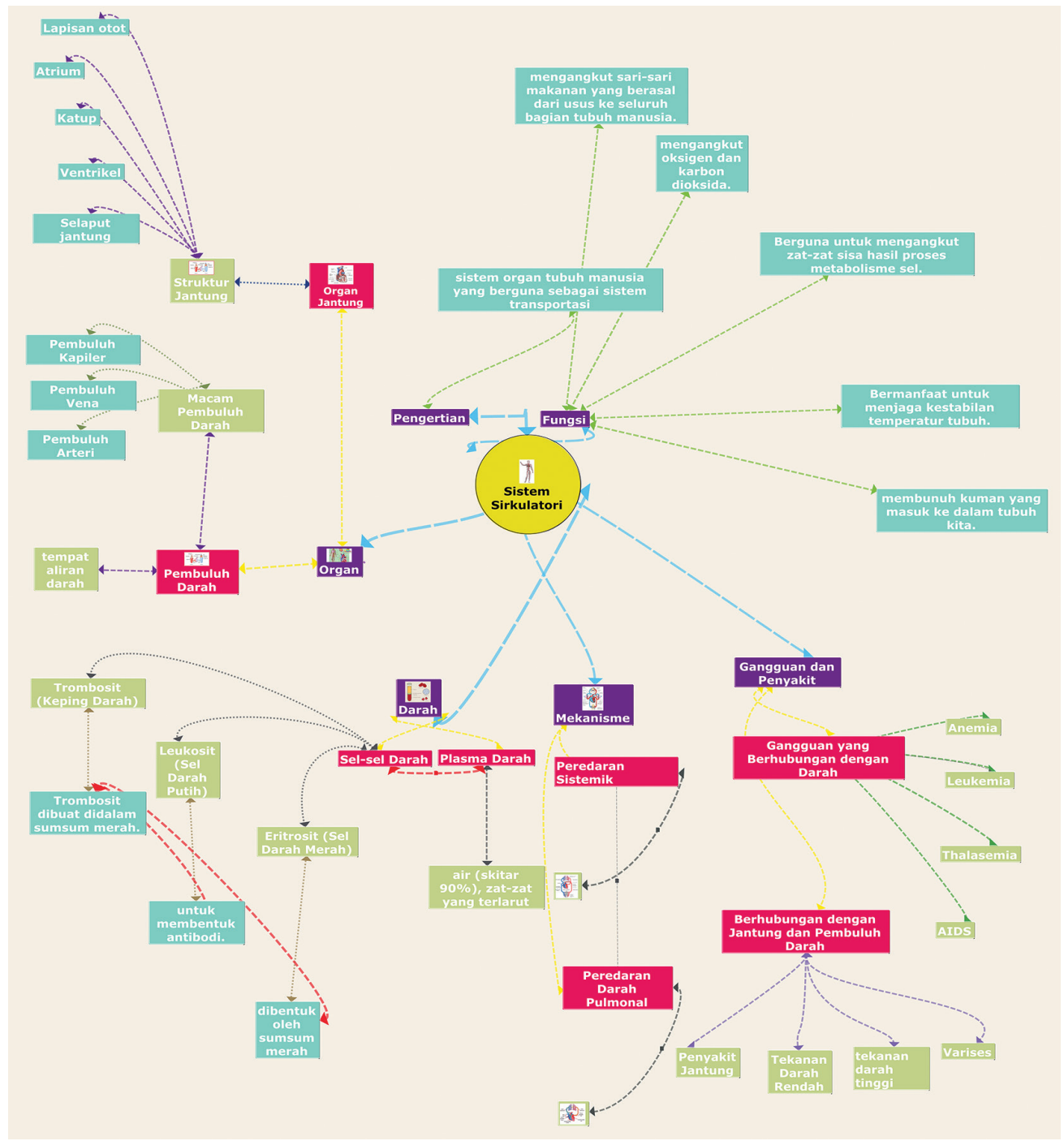

Figure 3. An Example of DMM on the Circulatory Using the Line Pattern 
The findings showed that every student had a different way of exploring colors, lines, branches, pictures, and videos to convey ideas (Chan, 2013). Research has proven that mind maps, either in the form of DMM or paper mind maps (PMM), can boost student creativity (Dell et al., 2012; Mahmud, Islam, \& Rawshon, 2013). DMM can affect student creativity because through DMM, students are allowed to be creative. They are allowed to combine the accuracy of the materials with various attractive images and to draw a mind map based on their preferences. Learning autonomy and flexibility can provide a foundation for students to explore their potentials and produce more creative ideas. Studies have shown that inflexible learning methods and rigid class schedules can hamper student creativity (Tan et al., 2016). Creating DMM requires a lot of kinetic movements and energy; therefore, students need to be creative (Edwards \& Cooper, 2010). DMM need to be informative and artistic. Thus, to make the map more informative, students need to be careful in choosing materials to be inserted into the map. Besides, to make the map more artistic, the students can select various colors or design a map that suits their preferences. The visualization of concepts or materials into colorful images is one of the aspects that can reflect student creativity (Ainsworth, Prain, \& Tytler, 2011).

Studies have shown that PBL can also affect student creativity (Alrahlah, 2016; Birgili, 2015; Bridges et al., 2012; Chan, 2013; Siew et al., 2017; Ulger, 2018; Zhou, 2015). One of the stages in PBL provides opportunities for students to develop their work. The students in this study were asked to make a video about someone who experienced spasm and compiled a report based on the predetermined problem statement. To be able to write an understandable and attractive report, the students, needless to say, had to generate ideas and explore their creativity. Since creativity is related to the ability to recognize ideas, find new solutions, and maximize efforts to produce something different (Al-oweidi, 2013; Batey, 2012; Hoseinifar et al., 2011), the report writing task can be one of the alternatives to improve student creativity (Tan et al., 2016).

In addition, the three different treatments (PBL, PBL-DMM, and traditional) provided the students with distinctive tasks, learning methods, and activities. Compared to the traditional class, the students in the PBL and PBL-DMM classes were able to achieve high scores in creativity. It was found that the lecturer of the traditional class often delivered learning materials through lectures, and there was no assignment designed for the students to foster their creativity. This ineffective pedagogical practice may result in poor student performance in creative skills because pedagogical practice is important in creativity coaching (Davies et al., 2013). Effective pedagogical practices include designing learning assignments that can stimulate creativity, create flexible and independent learning experiences, and present an open and collaborative atmosphere to communicate.

The results of this study have proven that PBL and PBL-DMM are effective in improving student creativity. Therefore, learning processes at colleges or universities should be focused on empowering student creativity. Equipped with creativity, university graduates are expected to be ready to be competitive in the work field and survive the 
$21^{\text {st }}$-century challenges. In addition to creativity, university students also need to arm themselves with other 21st century skills namely critical thinking (Butler, Pentoney, \& Bong, 2017; Zubaidah, Mahanal, Rosyida, Lutfi, Sholihah, \& Ismirawati, 2018;), creative thinking (Ersoy \& Başer, 2014; Fuad et al., 2017; Yusnaeni et al., 2017), communication skills (Taveira-Gomes, Mota-Cardoso, Figueiredo-Braga, 2016; Yusof \& Halim, 2014), and behavioral skills (Said, Al-emadi, Friesen, \& Adam, 2018).

\section{Conclusions and Recommendations}

Based on the findings of this study, it can be concluded that the two learning models, Problem Based Learning (PBL) and Integrated Problem Based Learning and Digital Mind Maps (PBL-DMM), have an effect on student creativity despite the fact that PBL-DMM is more effective in improving student creativity.

This research has been conducted only to a certain level of education and discipline. Therefore, future researchers should consider exploring the effectiveness of PBL and PBLDMM in a wider context, such as at different education levels and in different fields. It is also recommended for further investigation to discuss gender as one of the research variables.

\section{Acknowledgment}

This research was supported by the Indonesia Endowment Fund for Education (LPDP), the Ministry of Finance of the Republic of Indonesia number FR2712018124893.

\section{References}

Ainsworth, S., Prain, V., \& Tytler, R. (2011). Drawing to Learn in Science. Science, 333(6046), 1096-097. https://doi:10.1126/science.1204153.

Alrahlah, A. (2016). How Effective Problem-based Learning (PBL) in Dental Education. A critical review. The Saudi Dental Journal, 28(4), 155-161. https://doi.org/10.1016/j.sdentj.2016.08.003.

Al-Oweidi, A. (2013). Creative Characteristics and Its Relation to Achievement and School Type among Jordanian Students. Creative Education, 4(1), 29-34.

Amponsah, S., Benjamin, A., \& Ernest, A. (2019). Lin's Creative Pedagogy Framework as a Strategy for Fostering Creative Learning in Ghanaian Schools. Thinking Skills and Creativity, 31(May 2018), 11-18. https://doi.org/10.1016/j.tsc.2018.09.002.

Applin, H., Williams, B., Day, R., \& Buro, K. (2011). A Comparison of Competencies between Problem-based Learning and Non-problem-based Graduate Nurses. Nurse Education Today, 31(2), 129-134. https://doi.org/10.1016/j.nedt.2010.05.003. 
Arends, R. I. 2012. Learning to Teach. New York. McGraww-Hill.

Batey, M. (2012). The Measurement of Creativity: From Definitional Consensus to the Introduction of a New Heuristic Framework. Creativity Research Journal, 24(1), 55-65. https://doi.org/10 $.1080 / 10400419.2012 .649181$.

Bell, S. (2010). Project-based Learning for the 21st century: Skills for the future. The Clearing House, 83(2), 39-43. https://doi.org/10.1080/00098650903505415.

Birgili, B. (2015). Creative and Critical Thinking Skills in Problem-based Learning Environments. Journal of Gifted Education and Creativity, 2(2), 71-80. https://doi.org/10.18200/ JGEDC.2015214253.

Birsa, E. (2018). Teaching Strategies and the Holistic Acquisition of Knowledge of the Visual Arts.

Center for Educational Policy Studies Journal, 8(3), 187-206. https://doi.org/10.26529/cepsj.39. Brand, G., Hendy, L., \& Harrison, R. (2015). Mining the Gap! Fostering Creativity and Innovative Thinking. Procedia Technology, 20(July), 79-84. https://doi.org/10.1016/j.protcy.2015.07.014. Bridges, S., McGrath, C., \& Whitehill, T. L. (Eds.). (2012). Problem-based Learning in Clinical Education: The Next Generation (Vol. 8). Springer Science \& Business Media.

Butler, H. A., Pentoney, C., \& Bong, M. P. (2017). Predicting Real-world Outcomes: Critical Thinking Ability is a Better Predictor of Life Decisions than Intelligence. Thinking Skills and Creativity, 25, 38-46.

Buzan, T. 2011. Learn to Mind Maps Book. Retrieved from http://www.tonybuzan.com/about/mindCarriger, M. S. (2015). Problem-based Learning and Management Development - Empirical and Theoretical Considerations. International Journal of Management Education, 13(3), 249-259. https://doi.org/10.1016/j.ijme.2015.07.003.

Castillo-vergara, M., Galleguillos, N. B., Cuello, L. J., Alvarez-marin, A., \& Acuña-opazo, C. (2018). Does Socioeconomic Status Influence Student Creativity? Thinking Skills and Creativity, 29(February), 142-152. https://doi.org/10.1016/j.tsc.2018.07.005.

Chan, S., \& Yuen, M. (2014).Personal and Environmental Factors Affecting Teachers' Creativityfostering Practices in Hong Kong. Thinking Skills and Creativity, 12, 69-77. https://doi. org/10.1016/j.tsc.2014.02.003.

Chan, Z. C. Y. (2013). Exploring Creativity and Critical Thinking in Traditional and Innovative Problem-based Learning Groups. Journal of Clinical Nursing, 22(15016), 2298-2307. https:// doi.org/10.1111/jocn.12186.

Chang, S., Wang, C., \& Lee, J. (2016). Do Award-winning Experiences Benefit Students' Creative Self-efficacy and Creativity? The Moderated Mediation Effects of Perceived School Support for Creativity. Learning and Individual Differences, 51, 291-298. https://doi.org/10.1016/j. lindif.2016.09.011.

Chen, B. (2016). Conscientiousness and Everyday Creativity among Chinese Undergraduate Students. Personality and Individual Differences, 102, 56-59. https://doi.org/10.1016/j. paid.2016.06.061.

Chu, S. K. W., Reynolds, R. B., Tavares, N. J., Notari, M., \& Lee, C. W. Y. (2017). 21st Century Skills Development Through Inquiry-based Learning: From Theory to Practice. Springer. 
Csikszentmihalyi, M. (2012). Commentary: Reflections on Some Dangers to Childhood Creativity. LEARNing Landscapes, 6(1), 19-25.

Cuthell, J., \& Preston, C. (2008). Multimodal Concept Mapping in Teaching and Learning: a MirandaNet Fellowship Project. In Society for Information Technology \& Teacher Education International Conference (pp. 1999-2007). Association for the Advancement of Computing in Education (AACE).

Darmawan, H. (2014). Improvement Student's Creativity in Designing IPA Learning Media Based Animation (PeningkatanKreativitasMahasiswadalamMerancang Media Pembelajaran Multimedia IPA berbasisAnimasi.Edukasi, 12(2), 193-204.

Davies, D., Jindal-snape, D., Collier, C., Digby, R., Hay, P., \& Howe, A. (2013). Creative Learning Environments in Education - a Systematic Literature Review. Thinking Skills and Creativity, 8, 80-91. https://doi.org/10.1016/j.tsc.2012.07.004.

Dell, B., Garrick, R., Romanowski, C., \& Slifka, M. (2012).Using Mind Mapping to Influence Creativity and Innovation.Institute of Technology. Retrieved from http://www.indiana. edu/ ciec/Proceedings_2012/Papers/ETD-351/ETD-351_Slifka.pdf.

Diakidoy, I. N., Constantinou, C. P., \&Constantinou, C. P. (2001). Creativity in Physics: Response Fluency and Task Specificity Creativity in Physics: Response Fluency and Task Specificity. Creativity Research Journal, 13(3), 401-410. https://doi.org/10.1207/S15326934CRJ1334.

Edwards, S., \& Cooper, N. (2010). Mind Mapping as a Teaching Resource. The Clinical Teacher, 7(4), 236-239. doi:10.1111/j.1743-498x.2010.00395.x.

Erdogan, Y. (2009). Paper-based and Computer-based Concept Mappings: The Effects on Computer Achievement, Computer Anxiety, and Computer Attitude. British Journal of Educational Technology, 40(5), 821-836. https://doi.org/10.1111/j.1467-8535.2008.00856.x.

Ersoy, E., \& Başer, N. (2014). The Effects of Problem-based Learning Method in Higher Education on Creative Thinking. Procedia - Social and Behavioral Sciences, 116, 3494-3498. https://doi. org/10.1016/j.sbspro.2014.01.790.

Faste, H., \& Lin, H. (2012).The Untapped Promise of Digital Mind Maps.In Proceedings of the SIGCHI Conference on Human Factors in Computing Systems (pp. 1017-1026). ACM.

Fraenkel, J.R \& Wallen, N.E (2009). How to Design and Evaluate Research in Education (7 $7^{\text {th }} \mathrm{ed}$ ). New York. McGraw-hill.

Frydenberg, M. E \& Andone, D. (2011). Learning for 21st Century Skills. IEEE's International Conference on Information Society, London, 27-29 June 2011, 314-318.

Fuad, N. M., Zubaidah, S., Mahanal, S., Suarsini E. 2017. Improving Junior High Schools' Critical Thinking Skills Based on Test Three Different Models of Learning. International Journal of Instruction, 10 (1), 101-116.

Gijbels, D., Dochy, F., Van den Bossche, P., \&Segers, M. (2005). Effects of Problem-Based Learning: A Meta-Analysis from the Angle of Assessment. Review of Educational Research, 75(1), 27-61. https://doi.org/10.3102/00346543075001027.

Greenstein, L. 2012. Assessing $21^{\text {st }}$ Century Skills: A Guide to Evaluating Mastery and Authentic Learning. United Kingdom: Sage Publication Ltd. 
Hansenne, M., \& Legrand, J. (2012). Creativity, Emotional Intelligence, and School Performance in Children.International Journal of Educational Research, 53, 264-268. https://doi.org/10.1016/j. ijer.2012.03.015.

Hariyadi, S., Corebima, A. D., \& Zubaidah, S. (2018). The Contribution of Mind Mapping, Summarizing and Questioning in the RQA Learning Model to Genetic Learning Outcomes. Journal of Turkish Science Education (TUSED), 15(1), 80-88. https://doi.org/10.12973/tused.10222a.

Hmelo-Silver, C. E. (2004). Problem-based Learning: What and how do Students Learn? Educational Psychology Review, 16(3), 235-266. https://doi.org/10.1023/B:EDPR.0000034022.16470.f3.

Hoseinifar, J., Mohammad, M., \& Rasoul, S. (2011). Social and An Investigation of the Relation between Creativity and Five Factors of Personality in Students. Procedia - Social and Behavioral Sciences, 30, 2037-2041. https://doi.org/10.1016/j.sbspro.2011.10.394.

Huang, P. S. (2017). An Exploratory Study on Remote Associates Problem Solving: Evidence of Eye Movement Indicators. Thinking Skills and Creativity, 24, 63-72. https://doi.org/10.1016/j. tsc.2017.02.004.

Johnstone, A. H., \& Otis, K. H. (2006). Concept Mapping in Problem based Learning: A Cautionary Tale Concept Mapping in Problem based Learning: a Cautionary Tale. Chemistry Education Research and Practice, 7(2), 84-95. https://doi.org/10.1039/B5RP90017D.

Kennett, Y. N., Levy, O., Kenett, D. Y., Stanley, H. E., Faust, M., \& Havlin, S. (2018). Flexibility of Thought in High Creative Individuals Represented by Percolation Analysis.PNAS Early Edition.https://doi.org/10.1073/pnas.1717362115.

Kim, K., Sharma, P., Land, S. M., \& Furlong, K. P. (2013). Effects of Active Learning on Enhancing Student Critical Thinking in an Undergraduate General Science Course. Innovative Higher Education, 38(3), 223-235. https://doi.org/10.1007/s10755-012-9236-x.

Kuo, H. C., Burnard, P., McLellan, R., Cheng, Y., \& Wu, J. (2017). The Development of Indicators for Creativity Education and a Questionnaire to Evaluate its Delivery and Practice. Thinking Skills and Creativity, 24, 186-198. https://doi.org/10.1016/j.tsc.2017.02.005.

Laampere, M., Matsak, E., \& Kippar, J. 2006. Integrating a Concept Mapping Tool into a Virtual Learning Environment: Pedagogical and Technological Challenges. In Concept maps: Theory, methodology, technology: Proceedings of the Second International Conference on Concept Mapping 1, 280-287.

Lebeničnik, M., Pitt, I., \& Starčič, A. I. (2015). Use of Online Learning Resources in the Development of Learning Environments at the Intersection of Formal and Informal Learning: The student as autonomous designer. Center for Educational Policy Studies Journal, 5(2), 95-113. Loyens, S. M. M., Kirschner, P. A., \& Paas, F. (2012). Problem-Based Learning. In K. R. Harris, S. Graham, \& T. Urdan (Eds.), APA Educational Psychology Handbook (pp. 403-425). Washington, DC: American Psychological Association.

Mahmud, I., Islam, Y. M., \& Rawshon, S. (2013). Engineering Creativity by Using Computer aided Mindmap. American Journal of Engineering Research (AJER), 2(7), 28-32.

Moutinho, S., Torres, J., Fernandes, I., \&Vasconcelos, C. (2015). Problem-Based Learning and Nature of Science: A Study with Science Teachers. Procedia - Social and Behavioral Sciences, 191, 1871-1875. https://doi.org/10.1016/j.sbspro.2015.04.324. 
Musadad, A. A. (2011). (Improvement of Creativity and Learning Outcomes Through Optimization of Creative Problem Solving Models in Teaching and Learning (PBM) in History Study Program FKIP - UNS (Peningkatan Kreativitas dan Hasil Belajar Sejarah Indonesia Kuno Melalui Optimalisasi Model Pemecahan Masalah Kreatif Dalam Proses Belajar Mengajar (PBM) di Prodi Sejarah FKIP - UNS). Journal Pendidikan Dan Kebudayaan, 17(1), 1-11.

NEA. (2012). An Educator's Guide to the "Four Cs". Retrieved from http://www.nea.org/assets/ docs/A-Guide-to-Four-Cs.pdf.

Noonan, M. (2013). Mind maps: Enhancing Midwifery Education. Nurse education today, 33(8), $847-852$.

Ongardwanich, N., Kanjanawasee, S., \& Tuipae, C. (2015). Development of 21 st Century Skill Scales as Perceived by Students. Procedia - Social and Behavioral Sciences, 191, 737-741. https:// doi.org/10.1016/j.sbspro.2015.04.716.

Onyon, C. (2012). Problem-based Learning: a Review of the Educational and Psychological Theory. Clin. Teach, 9(1), 22-26. Retrieved from 10.1111/j.1743-498X.2011.00501.x.

Osman, K., \& Kaur, S. J. (2014). Evaluating Biology Achievement Scores in an ICT Integrated PBL Environment. Eurasia Journal of Mathematics, Science and Technology Education, 10(3), 185-194. https://doi.org/10.12973/eurasia.2014.1076a.

O'Grady, M. J. (2012). Practical Problem-based Learning in Computing Education. ACM Transactions on Computing Education (TOCE), 12(3), 10.

Papushina, I., Maksimenkova, O., \& Kolomiets, A. (2017). Digital Educational Mind Maps: A Computer Supported Collaborative Learning Practice on Marketing Master Program. Interactive Collaborative Learning, 17-30. https://doi.org/10.1007/978-3-319-66471-2.

Pheeraphan, N. (2013). Enhancement of the 21 st Century Skills for Thai Higher Education by Integration of ICT in Classroom.Procedia - Social and Behavioral Sciences, 103, 365-373. https://doi.org/10.1016/j.sbspro.2013.10.346.

Pumahapinyo, S., \& Suwannatthachote, S. (2014). Factors Affecting the Innovation-Decision Process to Adopt Online Graduate Degree Program in Thailand.In The Proceedings of International e-Learning Conference 2014, Bangkok, Thailand.

Qi, A. (2018). A Study of the Effect of Implementing Intellectual Property Education with Digital Teaching on Learning Motivation and Achievements. Eurasia Journal of Mathematics, Science \& Technology Education, 14(6), 2445-2452.https://doi.org/doi.org/10.29333/ejmste/89498.

Ravindranath, S., Abrew, W. K. De, \& Nadarajah, V. D. (2016). Student' s perception of mind mapping in Problem-based learning. Journal of Contemporary Med Ical Education, 4(2), 60-66. https://doi.org/10.5455/jcme.20160620013341.

Reid, A., \& Petocz, P. (2004). Learning Domains and the Process of Creativity. The Australian Educational Researcher, 31(2), 45-62. Retrieved from https://doi.org/10.1007/BF03249519\%0A.

Said, Z., Al-emadi, A. A., Friesen, H. L., \& Adam, E. (2018). Assessing the Science Interest, Attitude, and Self-efficacy of Qatari Students at the Preparatory, Secondary, and University Levels. Eurasia Journal of Mathematics, Science and Technology Education, 14(12). https:// doi.org/10.29333/ejmste/94733. 
Siew, N. M., Chin, M. K., \& Sombuling, A. (2017). The Effects Of Problem Based Learning With Cooperative Learning on Preschoolers' Scientific Creativity. Journal of Baltic Science Education, 16(1), 100-112.

Simándi, S. (2018). Lifelong Learning and Web 2.0 Tools: Online Study Circles for Supporting Active Learning and Citizenship. Pedagogika, 131(3), 67-82.

Simmons, A. L., \& Ren, R. (2009). The Influence of Goal Orientation and Risk on Creativity. Creativity Research Journal, 21(4), 400-408.

Simonova, I. (2015). E-learning in Mind Maps of Czech and Kazakhstan University Students. Procedia - Social and Behavioral Sciences, 171, 1229-1234. https://doi.org/10.1016/j. sbspro.2015.01.236.

Siwczuk, E. (2005). Mind Maps a Creative Thinking Tool. Technical Sciences, (8), 313-326.

Tan, L. S., Lee, S. S., Ponnusamy, L. D., Koh, E. R., \& Tan, K. C. K. (2016). Fostering Creativity in the Classroom for High Ability Students: Context Does Matter. Education Sciences, 6(4), 36.https://doi.org/10.3390/educsci6040036.

Taveira-Gomes, I., Mota-Cardoso, R., Figueiredo-Braga, M. (2016). Communication Skillss in Medical Students - An Exploratory Study Before and After Clerkships. Porto Biomedical Journal, 28(2016), 1-8.

Turganbayeva, B. A., \& Moshkalov, A. (2013). The Impact of ICT on the PersonaL self-development of students. Pedagogika, 110(2), 80-86.

Turiman, P., Omar, J., Daud, A. M., \& Osman, K. (2012). Fostering the 21 st Century Skills through Scientific Literacy and Science Process Skills. Procedia - Social and Behavioral Science, 59, 110-116. https://doi.org/10.1016/j.sbspro.2012.09.253.

Tyagi, V., Hanoch, Y., Hall, S. D., Runco, M., \& Denham, S. L. (2017). The Risky Side of Creativity: Domain Specific Risk Taking in Creative Individuals. Frontiers in Psychology, 8(February), 1-9. https://doi.org/10.3389/fpsyg.2017.00145.

Ulger, K. (2018). The Effect of Problem-Based Learning on the Creative Thinking and Critical Thinking Disposition of Students in Visual Arts. Interdisciplinary Journal of Problem-Based Learning, 12(1), 3-6. Retrieved from doi.org/10.7771/1541-5015.1649.

Vasilyeva, K. K., \& Erdyneeva, K. G. (2016). Learning Chinese as a Social and Cultural Factor of in Developing Creativity in Primary School Children. Procedia - Social and Behavioral Sciences, 233(May), 433-439. https://doi.org/10.1016/j.sbspro.2016.10.180.

Vong, S. A., \& Kaewurai, W. (2017). Instructional Model Development To Enhance Critical Thinking and Critical Thinking Teaching Ability of Trainee Students at Regional Teaching Training Center in Takeo Province, Cambodia. Kasetsart Journal of Social Sciences, 38(1), 88-95. https://doi.org/10.1016/j.kjss.2016.05.002.

Wu, C. H., Cheng, Y., Ip, H. M., \& McBride-Chang, C. (2005). Age Differences in Creativity: Task Structure and Knowledge Base. Creativity Research Journal, 17(4), 321-326. https://doi. org/10.1207/s15326934crj1704. 
Wu, C. L., Chang, Y. L., \& Chen, H. C. (2017). Enhancing the Measurement of Remote Associative ability: A New Approach to Designing the Chinese Remote Associates Test. Thinking Skills and Creativity, 24, 29-38.https://doi.org/10.1016/j.tsc.2017.02.010.

Wyness, L \& Dalton, F. (2018). The Value of Problem-based Learning in Learning for Sustainability: Undergraduate Accounting Student Perspectives. Journal of Accounting Education, (September), 1-19. https://doi.org/10.1016/j.jaccedu.2018.09.001.

Yates, E., \& Twigg, E. (2017).Developing Creativity in Early Childhood Studies Students. Thinking Skills and Creativity, 23, 42-57. https://doi.org/10.1016/j.tsc.2016.11.001.

Yusnaeni, Corebima, A. D., Susilo, H., \&Zubaidah, S. (2017). Creative Thinking of Low Academic Student Undergoing Search Solve Create and Share Learning Integrated with Metacognitive Strategy. International Journal of Instruction, 10(2), 245-262. https://doi.org/10.12973/ iji.2017.10216a.

Yusof, F.M \&Halim, H. 2014.Understanding Teacher Communication Skills. Procedia - Social and Behavioral Sciences, 155(2014), 471-476.

Zhou, C. (2015). Bridging Creativity and Group by Elements of Problem-Based Learning (PBL). In Pattern Analysis, Intelligent Security and the Internet of Things (pp. 1-9). Springer, Cham. Zubaidah, S., Mahanal, S., Rosyida, F., Lutfi, Z. K., Sholihah, M., \& Ismirawati, N. (2018). Using Remap-TmPS Learning to Improve Low-ability Students' Critical Thinking Skills. Asia-Pacific Forum on Science Learning and Teaching, 19(1), 1-28.

\section{Appendix 1}

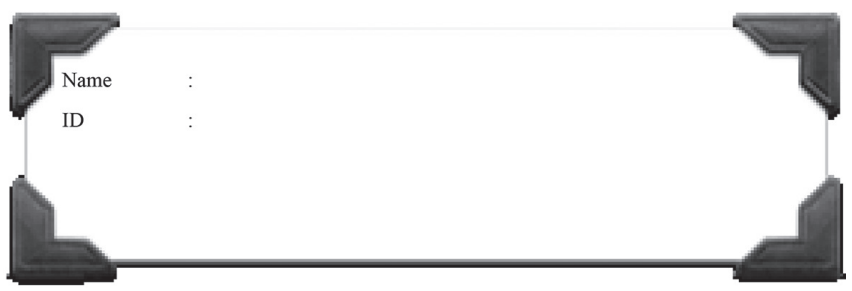

\section{CREATIVITY TEST}

\section{INSTRUCTIONS}

1. Please write your identity on the space provided.

2. Read the questions carefully.

3. Write your answer directly on the question sheet.

4. You have 90 minutes to complete this test.

5. This test encourages you to use your creativity, explore new ideas, and solve new problems. 


\section{QUESTIONS}

1. The following keywords should be used as the main topics of mind maps. Choose one of the words and create a mind map based on it! Then, give your mind map a title!
a. Blood
b. Muscle
c. Gastric

2. Look at the figures below. Choose one of the pictures that are appealing to you and explain why! If a glass of milk is added to each of the pictures, will you still choose the same picture or will you change your preference? Explain why!

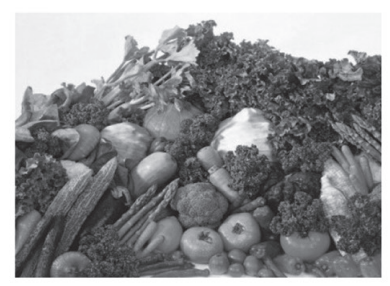

Figure 1. Vegetable

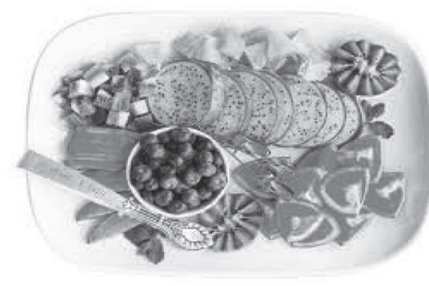

Figure 2. Fruit

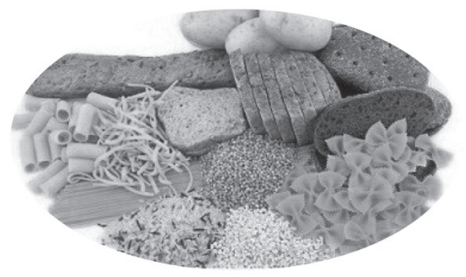

Figure 3. Bread and Noodles

3. You are involved in social activities in a remote village. There, you find many children and toddlers experience abdominal pain, suffer from stomach cramps, and have runny stools. What scientific question do you want to examine? Write down as many questions as possible. For example, "Where do the people get clean water from?"

4. Look at the following picture. If the picture is used to explain organ systems in the human body, what details can you add to the picture (picture/symbol/text).

5. In 2015, the forest fire in Riau has potentially caused a smog disaster. The haze might contain substances which are harmful to the respiratory organs such as carbon monoxide, methane, ammonia, and sulfur dioxide. As a biology student, what will you do to reduce the harm? Write down as many efforts or steps as possible.

6. A kidney-failure patient receives a dialysis treatment from a hospital. After years of undergoing dialysis, he learned that kid-

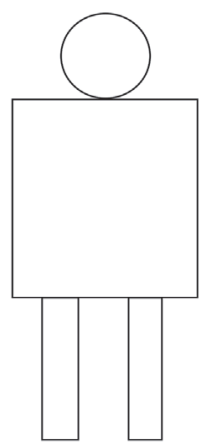
ney failure could be helped by a kidney transplant. But he still has doubts between continuing to do dialysis or kidney transplantation because both methods have their own risks. If you are asked to give advice to the patient (dialysis or kidney transplantation), what advice would you give? Give the reason!

7. Make a writing composition that contains as many "bone" words as possible so that the ideas can flow logically!

8. While on a trip, you saw someone fall from a motorcycle and suffered a cut on his leg that produced a lot of blood. The people around the location have provided first aid by closing the wound, but the blood was still flowing. What would you do in a situ- 
ation like this? Connect the decisions you take with the knowledge you have about the circulatory system!

9. Keira and Selly were running on the school ground. After running for about 30 minutes, Keira felt exhausted and fainted immediately. Selly knew that pungent aroma stimulation such as that possessed by cajuput oil could be used to wake up someone who has passed out. But at that time, Selly was not able to find cajuput oil nearby. If you had been Selly, what steps would you have taken to wake Keira up? Provide reasons!

10. Use a combination of the following two shapes (diamond and rectangle) to make a picture that can explain the organ system in the human body. Include the diamond and the rectangle as part of the picture that you are about to make. The diamond and rectangular shapes can be used more than once to produce meaningful images. Try to think of images that no one can think. Add details to tell the full story with your picture and provide the picture with a title!

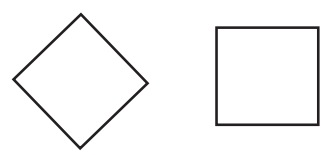

11. Suppose that there are two physically healthy people standing before you. How can you test the health of these two people's kidneys? Please write down any possible methods, simple principles, and procedures that you can do to examine their kidneys.

\title{
Integruotas probleminis mokymasis ir skaitmeniniai minčiu žemèlapiai: mokymosi modelis studentų kūrybiškumui gerinti
}

\author{
Nurkhairo Hidayati ${ }^{1}$, Siti Zubaidah ${ }^{2}$, Endang Suarsini ${ }^{3}$, Henry Praherdhiono ${ }^{4}$
}

1 Negeri Malango universitetas, Biologijos mokymo katedra, ID-65145, Malangas, Rytu Javos provincija, Indonezija; Islam Riau universitetas, Biologijos mokymo katedra, ID-28284, Pekanburu, Indonezija, khairobio@edu.uir.ac.id

2 Negeri Malango universitetas, Biologijos mokymo katedra, ID-65145, Malangas, Rytų Javos provincija, Indonezija, siti.zubaidah.fmipa@um.ac.id

3 Negeri Malango universitetas, Biologijos mokymo katedra, ID-65145, Malangas, Rytų Javos provincija, Indonezija, endang.suarsini.fmipa@um.ac.id

3 Negeri Malango universitetas, Švietimo technologijų katedra, ID-65145, Malangas, Rytų Javos provicija, Indonezija, henrypraherdhiono.fip@um.ac.id

\section{Santrauka}

Šis tyrimas pagrịstas studentų kūrybiškumo svarba, ypač vykstant šios epochos progresui. Atsižvelgiant ị tai, kad Indonezijoje daugumai studentų trūksta kūrybiškumo, būtina rasti sprendimą, kaip pagerinti studentų kūrybiškumą. Kūrybiškumas susideda iš sugebejimo vystyti ịvairias ir unikalias idejjas bei kurti daugybę problemos sprendimų 
būdų. Kūrybiškumo rodikliai apima originalumą, sklandumą, lankstumą, kruopštumą ir rizikos prisièmimą. Kūrybiškumas gali būti ịgalinamas pasitelkiant probleminị mokymąsi (angl. Problem Based Learning) arba integruojant skaitmeninius minčių žemèlapius (angl. Digital Mind Maps) ir probleminị mokymąsi (angl. Problem Based Learning) (sutr. angl. $P B L-D M M)$. Šiuo tyrimu buvo siekiama patikrinti mokymosi modelio efektyvumą studentų kūrybiškumui gerinti. Atliekant ši eksperimentinį tyrimą, prieš testą ir po testo buvo pasitelkta kontrolinė grupé, kurią sudarẻ 103 būsimi priešmokyklinio ugdymo pedagogai iš Indonezijos Riau universiteto, Biologijos mokymo katedros. Dalyvių kūrybiškumui ịvertinti buvo parengtas kūrybiškumo testas ir balų lentelè. Rezultatai parodè, kad probleminio mokymosi ir integruoto probleminio mokymosi su skaitmeniniais minčių žemèlapiais modeliai turèjo įtaką moksleivių kūrybiškumui. Tiesą sakant, lyginant probleminio mokymosi modeli, integruotas probleminio mokymosi su skaitmeninių minčių žemèlapiais modelis buvo veiksmingesnis mokinių kūrybiškumui gerinti. Abu - probleminio mokymosi modelis ir integruotas probleminio mokymosi su skaitmeninių minčių žemèlapiais modelis - gali būti naudojami klasẻje, siekiant skatinti mokinių kūrybiškumą. Todèl rekomenduojama šiuos mokymosi modelius diegti klasėse.

Esminiai žodžiai: mokymosi modelis, studentu kūrybiškumas, probleminis mokymasis, skaitmeniniai minčiu žemèlapiai.

Gauta 20190207 / Received 07022019

Priimta 20191001 / Accepted 01102019 